\title{
Does Genetic Engineering Influence the Nutritional Value of Plums? Case Study on Two conventional and One Genetically Engineered Plum Fruits
}

Otilia BOBIŞ ${ }^{1}$, Victoriţa BONTA ${ }^{1}$, Liviu A. MĂRGHITAŞ², Daniel S. DEZMIREAN ${ }^{2}$, Claudia PAŞCA², Adriana URCAN ${ }^{2}$, Erzsebet Timea DOMOKOS ${ }^{2}$, Adela Ramona MOISE ${ }^{2}$

${ }^{1}$ Life Science Institute "King Michael I of Romania", University of Agricultural Sciences and Veterinary Medicine - 400372, Cluj-Napoca, Mănăștur, 3-5, România

${ }^{2}$ Faculty of Animal Science and Biotechnologies, University of Agricultural Sciences and Veterinary

Medicine - 400372, Cluj-Napoca, Mănăștur, 3-5, România

*corresponding author: victorita.bonta@usamvcluj.ro

Bulletin UASVM Animal Science and Biotechnologies 76(1)/ 2019

Print ISSN 1843-5262; Electronic ISSN 1843-536X

DOI:10.15835/buasvmcn-asb: 2019.0003

\begin{abstract}
Plums are low-calorie fruits with a low glycaemic index score. Prunus domestica L. is one of the tree fruits threatened by Plum pox potyvirus (PPV), a quarantine disease that causes fruit loss to plums and other stone fruits. HoneySweet is a plum tree created to be resistant to this virus. Beside genetical determinations, chemical composition and nutritional value are important for a future acceptance in the cultivation of this type of fruit trees. Two conventional (Renclod Althan and Stanley) and one genetically engineered (HoneySweet) plum fruits were evaluated for the nutritional value determination. The analyzed samples showed nutritionally valuable features. HoneySweet variety had a balanced content of individual carbohydrates. The total lipid content had values quite close to the HoneySweet and Stanley varieties, far superior to Renclod Althan variety. HoneySweet transgenic plum had the highest total protein content. Also, HoneySweet variety is distinguished by a balanced protein and lipid content. By comparing the three analyzed varieties from the perspective of the most important physic-chemical nutrients (carbohydrates, proteins and lipids), the highest nutritional value was registered in Stanley variety, closely followed by HoneySweet, and then by Reine Claude d'Althan.
\end{abstract}

Keywords: Prunus domestica, Plum pox potyvirus, genetically engineered, nutritional value

\section{Introduction}

Delicious and juicy, plums botanically belong to the Rosaceae family, "drupe" fruits from the genus Prunus. Scientific name of plums is Prunus domestica $L$. It is cultivated all over the world at commercial scale as different cultivars. These cultivars differ in their color, size, shape and other growth characteristics.

Due to their nutritive value and high amounts of bioactive compounds, plums are recommended as dietary fruits that should not be missing from our diet, also because of their low calories and many other health promoting compounds such as flavonoids, anthocyanins, carotenoids, minerals (Bobiş et al., 2017, Voća et al., 2009, WalkowiakTomczak, 2008).

The complex chemical composition of plums, make them one of the most important fruits, consumed fresh or subjected to industrialization. The high content of sodium and potassium, the equilibrate sugar content (Bobiș et al., 2017), give these fruits also different health benefits (Mehta et al., 2014, Igwe and Charlton, 2016, Wallace, 2017). The antioxidant activity of plums is due to 
their polyphenolic content (Li et al., 2016, Miletic et al. 2013, Mihalache Arion et al., 2014, Rop et al., 2009, Sahamishirazi et al., 2017).

Plums are fruits with low calorie content; have low protein content and no saturated fats. Different health benefits are due to the compounds present in plums such as dietary fibers, sorbitol and isatin. These compounds have been found to help regulate the digestive system function, helping relieve the constipations problems. Other important health benefit is the antioxidant potential due to the vitamin $\mathrm{C}$ content, which is a very powerful natural antioxidant and also to the phenolic content. Vitamin C helps the organism scavenge harmful free radicals and infectious agents. The other vitamins present in plums are vitamin A and $B$-carotene. Vitamin-A is essential for good eyesight. It also required for maintaining healthy mucosa and skin. Consumption of natural fruits rich in vitamin-A has found to protect from lung and oral cavity cancers. The presence of carotenoids (lutein, cryptoxanthin, zeaxanthin) and anthocyanins in plums make them important scavengers against oxygen-derived free radicals and reactive oxygen species (ROS), which play an important role in aging and different disease processes. Zeaxanthin, an important dietary carotenoid selectively absorbed into the retinal macula lutea where it is thought to provide antioxidant and protective UV light-filtering functions.

Plums are rich sources of minerals like potassium, fluoride and iron. Iron is required for red blood cell formation. Potassium is an important component of cell and body fluids that helps controlling heart rate and blood pressure.

Plum pox virus (PPV) which causes Sharka disease is considered the most devasting pathogen of Prunus species (Cambra et al., 2006). It often produces severe symptoms on fruits and premature droping causing serious losses, biochemical modification in fruits affecting its quality (Pattantyus and Minoiu, 1983, Zagrai et al., 2002). The development of resistant plum cultivars is the future effective strategy to reduce the economical losses caused by PPV and genetic engineering was used as a complementary aproach to conventional breeding. One transgenic line, named 'HoneySweet' was developed in the last 15 years (Scorza et al., 2013) as the first genetically engineered Plum pox virus - resistant plum cultivar (Scorza et al., 2016). This transgenic line is now grown in a new field trial in Bistrita Research Station to determine the agronomical and phenotype performances of this genetically engineered tree in the geo-climatic conditions of Romania (Zagrai and Zagrai, 2008, Zagrai et al. 2008, Zagrai et al., 2010).

The conventional plum species analyzed in this study were Stanley and Reine Claude d'Althan. Stanley is a European self-fertile blue plum with golden flesh of the fruits. It's ripening in August giving very sweet fruits with a blue dark skin, high in natural pigments from the class of anthocianins. Is a self fertile tree, but pollinated by insects will maximize the production of fruits. It is recommended to be an excellent attractant and nectar source for bees and other beneficial insects.

Reine Claude d'Althan is an old plum cultivar from Central Europe. It has large round tasty fruits with a good flavor, weight 45-58 g, golden-yellow juicy flesh and different skin colours, ripening in the second half of August (Ionică et al., 2013).

The main objective of the present study was to determine by modern techniques, the chemical composition determining the nutritional value of HoneySweet fruits and if its chemical composition is in the range of other valuable plum cultivars (Stanley and Reine Claude d'Althan).

\section{Material and methods}

Samples. Plum samples of three different cultivars were provided by Fruit Research and Development Station Bistrita, Romania, harvested in 2017 in their full ripening stage. Samples were kept in the freezer as fresh fruits, until analysis. For a better extraction of the components, samples were minced in a porcelain mortar at the time of analysis.

Nutritional components. Chemical composition was determined by analyzing water content, total proteins and lipids, total sugar content and individual sugar spectrum, vitamin $\mathrm{C}$, as well as sodium and potassium content. Standard or own developed methods were used for the analysis.

Water content/Dry matter content. Water content was determined by drying an amount of grounded fruit until constant weight. An amount of $5 \mathrm{~g}$ was weighted on a glass and placed at $90^{\circ} \mathrm{C}$ in oven (Binder Germany), for 4 hours. After this period, the sample was cooled in exsicator, 


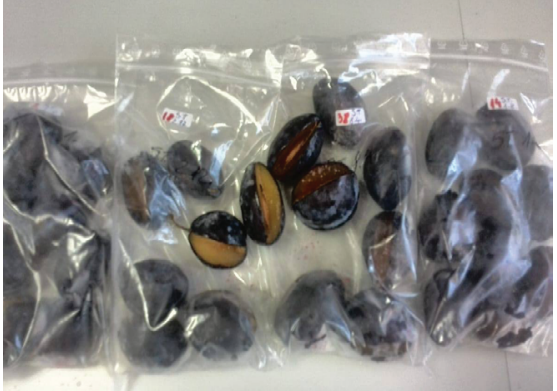

A

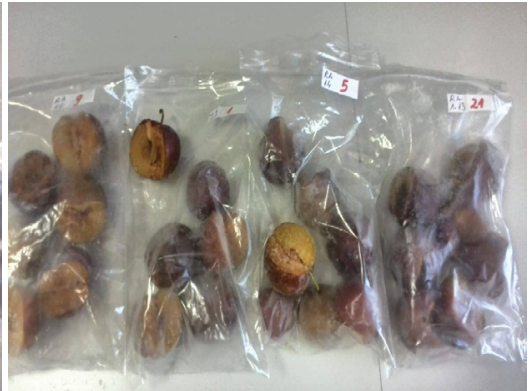

B

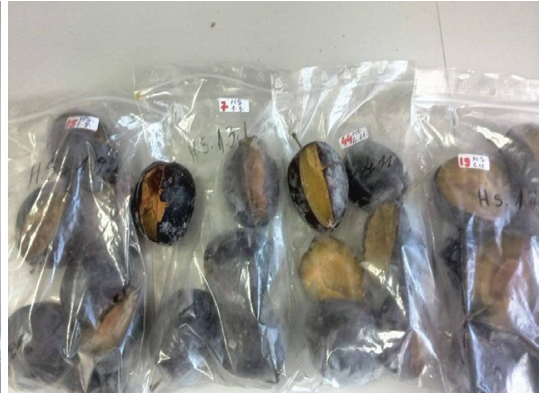

C

Figure 1. The three plum varieties subjected to analysis: A - Stanley; B - Reine Claude d'Althan; C - HoneySweet

weighted and placed again in the oven for another hour. This process was repeated until the difference between two weighters is only on fourth decimal. Dry matter content was determined by calculation (100 - water content), and expressed as $\mathrm{g} / 100 \mathrm{~g}$ (\%).

Total sugar content ( ${ }^{\circ}$ Brix). Total sugar determination was made by refractometer.

For this determination, 2-3 drops of fresh swuessed plum juice is placed on the prism of the apparatus and Brix value (Unit for measuring the sugar content of an aqueous solution) are read. The correspondence of Brix to sugar content is: 1 ${ }^{\circ}$ Brix $=10.04 \mathrm{~g} /$ liter at $20^{\circ} \mathrm{C}$.

Individual sugar spectrum. Individual sugar spectrum was determined using high performance liquid chromatography with refractive index detection.

Samples were prepared according to Bonta et al. (2010), adapted to fruits analysis.

Sugar standard solutions were prepared analoguously as the sample. They are injected and analysed separately to determine the retention time of each sugar and than in mixture for the calibration curve construction. Results are expressed as $\mathrm{g} / 100 \mathrm{~g}(\%)$.

Total lipid content. Total lipids were determined by extraction with organic solvents using Soxhlet method. 2 g of sample were weighted on filter paper, which will be packed and placed in the paper cartridge. Dry and clean extraction glasses containing 2 boiling stones, will be weighted and together with the cartridge and the solvent ( $70 \mathrm{ml} \mathrm{n}$-hexane) will be fixed in PTFE cylinders.

The method is set from the multistat:

- extraction temperature $140{ }^{\circ} \mathrm{C}$,

- extraction time $3 \mathrm{~h}, 25 \mathrm{~min}$,

- washing $30 \mathrm{~min}$,
- solvent evaporation in hot air flow 10min.

After extraction the glasses are placed in the oven at $60{ }^{\circ} \mathrm{C}$, for one hour, to eliminate traces of solvent and weighted for the result calculation as percent.

Total nitrogen content (total proteins). From the homogenized sample, $1 \mathrm{~g}$ is weighted in paper bags handled with a tweezer so that they are not contaminated with different substances that may contain nitrogen. Paper bags are placed in digestion unit vialse (Buchi Digesion Unit K-424), with 2 Kjeldahl tablets and $20 \mathrm{ml}$ concentrated sulphuric acid sulfuric (95-98\%). Digestion lasts 2 $\mathrm{h}$, until the solution turns to green.

Distilation is made with Büchi, KjelFlex K-360 unit, every determination is made with $50 \mathrm{ml} \mathrm{H}_{2} \mathrm{O}$ : $90 \mathrm{ml} \mathrm{NaOH}$ : $60 \mathrm{ml} \mathrm{H}_{3} \mathrm{BO}_{3}$.

Titration is made with automatic titrator TitroLine Eeasy (Schott), using $0.05 \mathrm{M}$ sulphuric acid for low protein matrices, until pH of 4.65.

Vitamin C determination. Vitamin $\mathrm{C}$ was determined titrimetrically. Chemical methods for determining the vitamin $\mathrm{C}$ are based on its reducing properties. Ascorbic acid is transformed by oxidation in dehydroascorbic acid using different oxidative agents. The determination must be made very quickly, because of the oxidation process. The content of vitamin $\mathrm{C}$ is calculated according to a specific formula.

The mineral content (sodium and potassium) of the plum samples was determined by atomic absorption spectrometry. To determine the levels of $\mathrm{Na}$ and $\mathrm{K}$ in the studied matrix (the three plum varieties) atomization absorption method was used in the THGA graphite furnace. An Aanalyst 800 atomic absorption spectrometer from PerkinElmer, equipped with a cross-linked graphite furnace was used. The amount of minerals was 


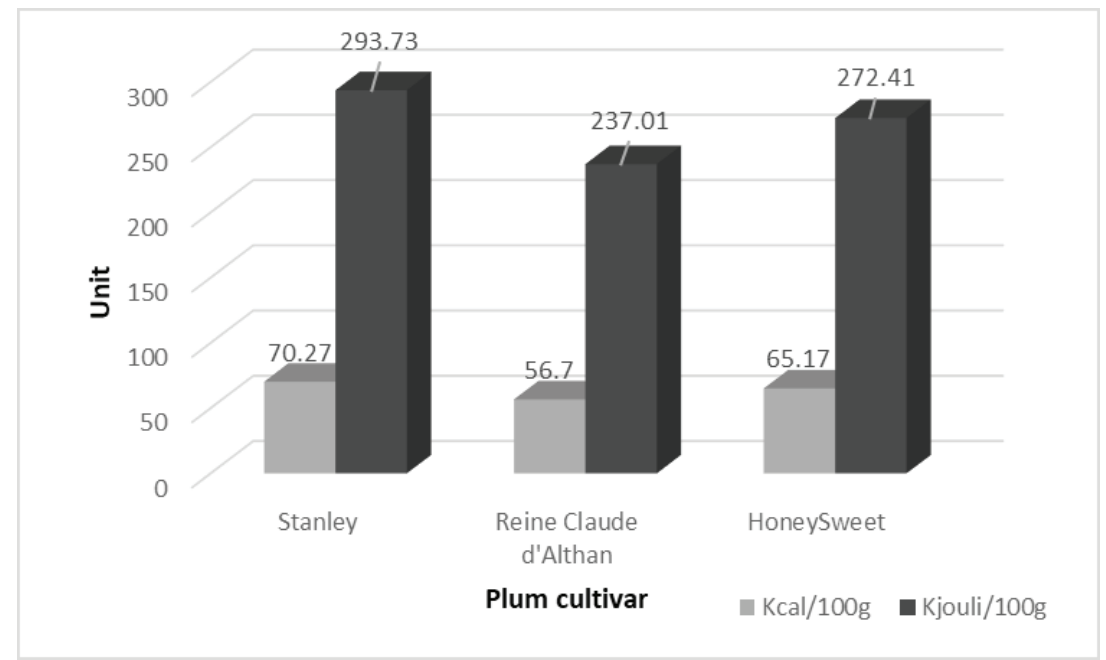

Figure 2. Energetic value of the analyzed plum samples from three cultivars.

determined by reading on a calibration curve of the standard minerals.

Nutritional value. Nutritional value of the samples was determined by calculation (Merrill and Watt, 1955). For this determination, analysis of sugars, proteins, lipids, water content were determined following the above-mentioned methods. The equation is:

Energetic value (nutritional value) $(\mathrm{kcal})=$ $4.1 \times$ (g proteins + g sugars $)+9.3 \times$ (g lipids)

The result is expressed in kcal or kjouls / 100 g sample.

\section{Results and discussions}

Main chemical composition parameters for the analyzed samples is presented in Table 1 . Some of the parameters differ significantly between cultivars, and others are similar regardless of the cultivar, results reported also in the literature studies (Botu et al., 2012; Ravelonandro et al., 2013; Hârța et al., 2016; Pop et al. 2018).

For plum samples harvested in 2017, water content lies between $78.13 \%$ (Stanley) and 82.65\% (Reine Claude d'Althan). Implicitly, the highest amount of dry weight was registered in Stanley variety, and the lowest in Reine Claude d'Althan.

Dry weight for different variants of HoneySweet cultivar (Ravelonandro et al., 2013) lies between 8.65 and $10.75 \%$, much lower than in our study $(18.05 \%)$ and lower values for Stanley variety (13.35\%), compared to our results (21.87\%).

Total amount of sugars expressed as ${ }^{\circ}$ Brix, presented similar values for Reine Claude d'Althan and HoneySweet variety and higher values for Stanley.

The study of Ravelonandro et al. (2013), show an amount of $10.00-11.17 \%$ soluble solids in five HoneySweet variants, lower than in our study, and an amount of $14 \%$ for Stanley variety (also lower than in our study). Similar results to those in our study were obtain by Milošević and Milošević (2012b) for Stanley variety.

The highest amount of sugars was quantified in Stanley variety (sum of fructose, glucose and sucrose). Regarding the literature data, Ravelonandro et al. (2013), obtained lower amounts of simple sugars for HoneySweet, Reine Claude d'Althan and Stanley varieties, compared to the results obtained in our study.

It is known that plums are not rich in lipids or proteins. Reine Claude d'Althan variety presented the lowest amount of total lipids (1.08 $\%)$, and HoneySweert variety the highest (1.92 $\%)$. According to different literature studies (Walkowiak-Tomczak, 2008, Ravelonandro et al., 2013), the fat content in plums lies between 0.1 şi $0.3 \%$. Our results show higher amounts of total lipids, compared to same cultivars analyzed by different authors (Milošević and Milošević, 2012a, Ravelonandro et al., 2013).

Protein content was similar to literature data (Ravelonandro et al., 2013), the highest amount of nitrogen, converted to protein was obtained in HoneySweet variety $(0.81 \%)$, followed by Stanley $(0.76 \%)$ and Reine Claude d'Althan $(0.67 \%)$.

Plum varieties analyzed in this study, revealed high amounts of potassium. Potasium was quantified in high amounts in Stanley variety (2360 
Table 1. Chemical composition of analyzed plum samples. Results represent the mean of three independent determinations \pm standard deviation

\begin{tabular}{cccc}
\hline Parameter/Plum variety & Reine Claude d'Althan & HoneySweet & Stanley \\
\hline Water content $(\%)$ & $\mathbf{8 2 . 6 5} \pm 1.54$ & $\mathbf{8 1 . 9 5} \pm 0.99$ & $\mathbf{7 8 . 1 3} \pm 2.45$ \\
\hline D.W. $(\%)$ & $\mathbf{1 7 . 3 5} \pm 1.54$ & $\mathbf{1 8 . 0 5} \pm 0.99$ & $\mathbf{2 1 . 8 7} \pm 2.45$ \\
\hline Soluble solids $\left({ }^{\circ}\right.$ Brix) & $\mathbf{1 6 . 0 5} \pm 0.88$ & $\mathbf{1 6 . 5 2} \pm 0.71$ & $\mathbf{2 0 . 2 0} \pm 0.74$ \\
\hline Fructose $(\%)$ & $\mathbf{2 . 1 0} \pm 1.31$ & $\mathbf{1 . 7 6} \pm 0.33$ & $\mathbf{2 . 5 8} \pm 0.26$ \\
\hline Glucose $(\%)$ & $\mathbf{4 . 5 4} \pm 0.56$ & $\mathbf{4 . 1 0} \pm 0.52$ & $\mathbf{5 . 6 1} \pm 0.57$ \\
\hline Sucrose $(\%)$ & $\mathbf{4 . 0 8} \pm 3.46$ & $\mathbf{4 . 8 7} \pm 0.56$ & $\mathbf{5 . 4 0} \pm 0.59$ \\
\hline Total simple sugars $(\%)$ & $\mathbf{1 0 . 7 1} \pm 5.34$ & $\mathbf{1 0 . 7 3} \pm 0.82$ & $\mathbf{1 3 . 5 9} \pm 0.92$ \\
\hline Total lipids $(\%)$ & $\mathbf{1 . 0 8} \pm 0.35$ & $\mathbf{1 . 9 2} \pm 0.59$ & $\mathbf{1 . 2 3} \pm 0.41$ \\
\hline Total proteins $(\%)$ & $\mathbf{0 . 6 7} \pm 0.04$ & $\mathbf{0 . 8 1} \pm 0.06$ & $\mathbf{0 . 7 6} \pm 0.06$ \\
\hline Vitamin C $(\mathrm{mg} / 100 \mathrm{~g})$ & $\mathbf{2 . 9 0} \pm 0.60$ & $\mathbf{9 . 3 6} \pm 0.96$ & $\mathbf{8 . 6 1} \pm 1.12$ \\
\hline Na $(\mathrm{mg} / \mathrm{kg})$ & $\mathbf{1 0 . 3 4} \pm 3.50$ & $\mathbf{1 8 . 0 8} \pm 4.14$ & $\mathbf{1 5 . 5 1} \pm 8.42$ \\
\hline K $(\mathrm{mg} / \mathrm{kg})$ & $\mathbf{1 9 8 6 . 0 8} \pm 728.57$ & $\mathbf{1 9 4 0 . 7 8} \pm 590.15$ & $\mathbf{2 3 6 0 . 0 1} \pm 653.58$ \\
\hline
\end{tabular}

$\mathrm{mg} / \mathrm{kg}$ ), followed by Reine Claude d'Althan (1986 $\mathrm{mg} / \mathrm{kg}$ ) and a slightly lower value in HoneySweet cultivar (1940 mg/kg).

Vitamin C, determined by titrimetric method, was in accordance with literature studies on the same varieties of plums, similar values were obtained by Ravelonandro et al. (2013) for the same cultivars (Stanley $9.5 \mathrm{mg} / 100 \mathrm{~g}$, HoneySweet $8.0 \mathrm{mg} / 100 \mathrm{~g}$ and Reine Claude d'Althan 2.5 $\mathrm{mg} / 100 \mathrm{~g})$.

Energetic values calculated based on the chemical composition in presented in Figure 2. Stanley variety presented the highest energetic value $(70.27 \mathrm{kcal} / 100 \mathrm{~g})$, closely followed by HoneySweet $(65.17 \mathrm{kcal} / 100 \mathrm{~g}$ ) and then by Reine Claude d'Althan $(56.70 \mathrm{kcal} / 100 \mathrm{~g})$. As stated in the literature, regardless of the variety of plums, they are valuable fruits with a low energetic value and healthy benefits.

\section{Conclusion}

The analyzed plum samples presented valuable characteristics from nutritional point of view. Comparing the three varieties, we can conclude that the variation between the nutritional characteristics is not significantly different, the genetically engineered plum cultivar, designed to be resistant to Plum pox potyvirus have the same nutritional characteristics, some of them being even better than those of the two conventional cultivars. The results from the present study were achieved under specific field and laboratory conditions, and further studies on consecutive years are needed to have a broader conclusion upon the genetically engineered variety, which have better performances for some characteristics, than the conventional varieties.

Aknowledgement: Financial support for this research was granted by the project ADER $413 / 2015$, developed through the Ministery of Agriculture and Rural Development, Romania. The authors declare no conflict of interests.

\section{References}

1. Bobiş 0 , Zagrai I, Bonta V, Zagrai L, Mărghitaş LA, Dezmirean DS, Paşca C, Urcan A (2017). Comparative studies on chemical composition of two conventional bred and one genetically engineered plum fruits. Bulletin UASVM Animal Science and Biotechnologies, 74(2): 149156.

2. Bonta V, Mărghitaş LA, Stanciu O, Laslo L, Dezmirean D, Bobis 0 (2008). High-Performance Liquid Chromatography analysis of sugars in Transilvanian Honeydew honey. Bulletin UASVM Animal Science and Biotechnologies, 65(1-2):229-232.

3. Botu I, Botu M, Papachatzis A, Cosmulescu S, Preda S (2012). Evolution of plum culture; constrains and perspectives. Acta Horticulturae, 968:19-24.

4. Cambra M, Capote N, Myrta A, Llácer G (2006) Plum pox virus and estimated costs associated to sharka disease. Bulletin OEPP/EPPO, 36: 202-204.

5. Hârţa M, Sisea CR, Pop R, Szabo K, Zărnescu M, Clapa D, Pamfil D (2016). The Current Status of Germplum Database: a Tool for Characterization of Plum Genetic Resources in Romania. Bulletin UASVM Horticulture, 73(2):240-241.

6. Igwe E, Charlton KE (2016). A systematic Review on the Health Effects of Plums (Prunus domestica and Prunus salicina), Phytotherapy Research, DOI: 10.1002/ptr.5581

7. Ionică ME, Nour V, Trandafir I, Cosmulescu S, Botu M (2013). Physical and chemical properties of some European plum cultivars. Notulae Botanicae Horti Agrobotanicae, 41(2):1-6. 
8. Li Y, Lai P, Chen J, Shen H, Tang B, Wu L, Weng M (2016). Extraction optimization of polyphenols, antioxidant and xanthine oxidase inhibitory activities from Prunus salicina Lindl. Food Science and Technology, Campinas, 36(3):520-525.

9. Mehta S, Soni N, Satpathy G, Gupta RK (2014). Evaluation of nutritional, phytochemical, antioxidant and antibacterial activity of dried plum (Prunus domestica). Journal of Pharmacognosy and Phytochemistry, 3(2):166-171.

10. Merrill AL, Watt BK (1955). "ENERGY VALUE By." Energy value of food basis and derivations United States Agriculture Handbook, 74

11. Mihalache Arion C, Tabart J, Kevers C, Niculaua M, Filimon R, Beceanu D, Dommes J (2014). Antioxidant potential of different plum cultivars during storage. Food Chemistry, 146: 485-491.

12. Miletić N, Mitrović O, Popović B, Nedović V, Zlatković B, Kandić M (2013). Polyphenolic content and antioxidant capacity in fruits of plum (Prunus domestica L.) cultivars "Valjevka" and "Mildora" as influenced by air drying. Journal of Food Quality, 36:229-237.

13. Milošević T, Milošević N (2012a). Factors influencing mineral composition of plum fruits. Journal of Elementology, 3: 453-464.

14. Milošević T, Milošević N (2012b). Main physical and chemical traits of fresh fruits of promising plum hybrids (Prunus domestica) from Carak (Western Serbia), Romanian Biotechnological Letters, 17(3):7358-7365.

15. Pattantyus K, Minoiu N (1983). Modificari biochimice induse de varsat (plum pox) la prun. Din contributia cercetarii stiintificela producerea materialului saditor pomicol liber de viroze, 133-149.

16. Pop R, Hârța M, Szabo K, Zanescu M, Sisea CR, Catana C, Pamfil D (2018). Genetic Diversity and Population Structure of Plum Accessions from a Romanian Germplasm Collection Assessed by Simple Sequence Repeat (SSR) Markers. Notulae Botanicae Horti Agrobotanicy ClujNapoca, 46(1):90-96.

17. Ravelonandro M, Scorza R, Polak J, Callahan A, Krska B, Kundu J, Briard P (2013). „HoneySweet” Plum - a valuable genetically engineered fruit-tree cultivar. Food and Nutrition Science, 4:45-49.

18. Rop O, Jurikova T, Mlcek J, Kramarova D, Sengee Z (2009). Antioxidant activity and selected nutritional values of plums (Prunus domestica L.) gtypical of the White
Carpathian Mountains. Sciencia Horticulturae, 122:545549.

19. Sahamishirazi S, Moehring J, Claupein W, GraeffHoenninger S (2017). Quality assessment of 178 cultivars of plum regarding phenolic, anthocyanin and sugar content. Food Chemistry, 214:694-701.

20. Scorza R, Callahan A, Dardick C, Ravelonandro M, Polak J, Malinowski T, Zagrai I, Cambra M, Kamenova I (2013). Genetic engineering of Plum pox resistance: "HoneySweet" plum - from concept to product. Plant Cell Tissue and Organ Culture, 115:1-12.

21. Scorza R, Ravelonandro M, Callahan A, Zagrai I, Polak J, Malinowski T, Cambra M, Levy L, Damsteeght Y, Krska B, Cordts J, Gonsalves D, Dardick C (2016). HoneeSweet (C5), the First Genetically Engineered Plum pox virus - resistant Plum (Prunus domestica L.) Cultivar. HortScience 51(5): 601- 603

22. Voća S, Galić A, Šindrak Z, Dobričević N, Pliestić S, Družić J (2009). Chemical composition and antioxidant capacity of three plum cultivars. Agriculturae Conspectus Scientificus, 74(3): 273-276

23. Walkowiak-Tomczak D (2008). Characteristics of plums as a raw material with valuable nutritive and dietary properties - A review. Polish Journal of Food and Nutrition Sciences, 58(4):401-405.

24. Wallace TC (2017). Dried Plums, Prunes and Bone Health: a Comprehensive Review, Nutrients, 9, 401, doi: 10.3390/ nu9040401.

25. Zagrai I, Maxim A, Florian V, Zagrai L, Oroian I, Țigăuan N (2002). Modificări biochimice induse de virusul plum pox în fructe la diferite soiuri, clone și hibrizi de prun. Revista de Protecția Plantelor Transilvania, Cluj-Napoca, 45:100110.

26. Zagrai I, Zagrai L, Preda S, Isac M, Cardei E (2010). Incidence od Plum pox virus in Romanian plum orchards. Bulletin UASMV Horticulture, 67(1):488.

27. Zagrai L, Zagrai I (2008). Non-transmission of Plum pox virus D and Rec stgrains through seeds in plum. Bulletin UASVM Horticulture, 65(1):523.

28. Zagrai L, Zagrai I, Ferencz B, Gaboreanu I, Kovacs K, Petricele I, Popescu O, Pamfil D, Capote N (2008). Serological and molecular typing of Plum pox virus isolates in the north of Romania. Journal of Plant Pathology, 90:4146. 